THE CONTENT OF PHOTOSYNTHETIC PIGMENTS IN THE LEAVES OF GALEGA OFFICINALIS L. AND GALEGA ORIENTALIS LAM. CULTIVARS

\author{
Shymanska Oksana, Vergun Olena*, Rakhmetov Jamal, Fishchenko Valentyna
}

M.M. Gryshko National Botanical Garden of NAS of Ukraine, Kyiv, Ukraine

Received 25. 6. 2017

Revised 29. 6. 2017

Published 29. 11. 2017

The present study aims to investigate the differences in leaf pigment content of plants of cultivars of Galega L. species. Plant raw material was collected in the spring vegetation stage, budding stage, flowering stage, and fruitage. Biochemical analyze of determination of pigments content was carried out with fresh mass of leaves (100 mg) of cultivars of Galega officinalis L. and Galega orientalis Lam. It was conducted the extraction of pigments in acetone. Obtained acetone extracts of leaves were prepared according to Musienko et al. (2001) and measured at wavelengths $662 \mathrm{~nm}$ (chlorophyll a), $644 \mathrm{~nm}$ (chlorophyll $b$ ) and $440 \mathrm{~nm}$ (carotenoids). To calculate concentration ( $\mathrm{mg} \%$ of fresh mass) of pigments was applied the equation of Holm-Wettstein. It was found the maximal sign of chlorophyll $a$ in the acetone extracts of Galega orientalis cv. NBS-75 (2.38 mg\%) at the flowering stage and minimal - in the leaves of Galega officinalis cv. Harant $(1.20 \mathrm{mg} \%)$ at the fruitage. Highest level of chlorophyll $b$ concentration was identified for Galega orientalis cv. NBS-75 (0.58 m\%) at the flowering stage and lowest - for Galega orientalis cv. Kavkazskiy branets $(0.19 \mathrm{mg} \%)$ at the spring vegetation period. As result, maximal accumulation of carotenoid concentration observed in the leaves of the plants of Galega orientalis cv. NBS-75 (1.05 mg\%) at the flowering stage and minimal - in the leaves of the plants of Galega orientalis cv. Kavkazskiy branets $(0.31 \mathrm{mg} \%)$ at the spring vegetation period. The results showed the ratio of chlorophylls content $(a / b)$ was in range from 3.12 (Galega orientalis cv. Kavkazskiy branets at the fruitage) to 10.10 (Galega orientalis cv. Saliut at the spring vegetation). Maximal and minimal ratio between chlorophylls and carotenoids content identified for Galega orientalis cv. NBS-75 and was in range from 2.40 (budding stage) to 6.79 (spring vegetation stage).

Keywords: Galega; chlorophyll $a$; chlorophyll $b$; carotenoids; pigment ratio

\title{
Introduction
}

Physiological indexes quite often use for the characteristic of plant resistance to different factors of environment. Amount of chlorophyll in leaf tissue is influenced by nutrient availability and environmental stresses such as drought, salinity, cold and heat etc. (Palta, 1990).

Galega officinalis L. is widely used in folk medicine as an antidiabetic or for increasing lactation (Shojaee, 2015). This plant has been used for treatment of the plague, malignant fevers, and parasitic infection and was also widely cultivated as cattle feed in ancient times. The ethanolic extracts of Galega officinalis were tested against both gram-positive and gram-negative bacteria as the plant was suggested to hasten skin healing after surgery, and the antibacterial effect was shown (Karakas, 2012). Antimicrobial activity of extracts of Galega officinalis against bacteria was more

*Corresponding author: Olena Vergun, M.M. Gryshko National Botanical Garden of NAS of Ukraine, Kyiv, Ukraine, $\triangle$ en_vergun@ukr.net 
effective than against fungus (Ozbucak et al., 2005). Plant raw material of these plants is rich source or biologically active compounds such as ascorbic acid, lipids, protein, carotene, amino acids etc. (Champavier, 1999; Balezentiene and Mikulioniene, 2006; Vergun, 2012). As reported Peiretti and Gai (2006) dry matter, organic matter, neutral detergent fibre, acid detergent fibre, lignin and gross energy increased during maturation, while the crude protein, ash of Galega orientalis decreased with increasing stage.

Moreover, as resulted Balezentiene and Spruogis (2011), biomass of Galega orientalis Lam. has better chemical content and metabolizable energy $(9.6 \mathrm{MJ} / \mathrm{kg}$ ) than traditional feed grasses and improved feed value and selective consumption of animal feeds.

\section{Materials and methodology}

Investigation was conducted in the laboratory of Cultural flora department of M.M. Gryshko National Botanical Garden of the NAS of Ukraine. Plant raw material of two cultivars of Galega officinalis and four cultivars of Galega orientalis collected during the vegetation period: at spring vegetation, budding stage, flowering stage, and fruitage. It was determined the content of leaf pigments (chlorophyll $a, b$ and carotenoids) by spectrophotometric method according to Musienko et al. (2001) in solution of acetone extracts. Work stages: extraction with acetone (100 $\mathrm{mg}$ of fresh mass per $20 \mathrm{~mL}$ ), spectrophotometric measuring at $662 \mathrm{~nm}$ (chlorophyll $a$ ), at $644 \mathrm{~nm}$ (chlorophyll $b$ ) and at $440 \mathrm{~nm}$ (carotenoids). Powder of $\mathrm{MgCO}_{3}$ was added to avoid destruction of pigments. To determine the density of pigment solvent was used a spectrophotometer UNICO 2800. The concentrations of pigments were calculated according to the equation proposed by Holm-Wettstein (Musienko et al., 2001). The results are given in $\mathrm{mg}$ per $100 \mathrm{~g}$ of fresh mass. Mean values and standard deviations are given in Tables 1-3, Figure 1, 2.

\section{Results and discussion}

Chlorophyll content is one of the indices of photosynthetic activity (Larcher, 1995). The chlorophyll is also plays important role in plant physiology and it can be act as nutrition in decline blood sugar conditions, detoxification, digestion and decreasing allergens. Leaf chlorophyll concentration is an important parameter that is regularly measured as an indicator of chloroplast content, photosynthetic mechanism and of plant metabolism. Chlorophylls are an oxidant compounds which are present and stored in the chloroplast of green leaf, stems, and flowers (Kamble et al., 2015)

Leaves of investigated plants accumulated chlorophyll $a$ in range from 1.20 to $2.38 \mathrm{mg} \%$ during vegetation (Table 1). The experimental results showed in the spring vegetation period, when shoots of plants have started to grow, the concentration of this pigment was in range $1.43-2.04 \mathrm{mg} \%$, in budding period - in range 1.27-2.09 $\mathrm{mg} \%$, in flowering stage - in range $1.51-2.38 \mathrm{mg} \%$, in fruitage in range $1.20-1.88 \mathrm{mg} \%$.

In Table 2 showed values of concentration of chlorophyll $b$ in the leaves of investigated cultivars of Galega officinalis and Galega orientalis. In the start of spring vegetation its sign was in range $0.19-0.50 \mathrm{mg} \%$, in the period of budding - in range $0.31-0.52 \mathrm{mg} \%$, in the flowering stage - in range $0.38-0.58 \mathrm{mg} \%$, in fruitage period - in range $0.24-0.54 \mathrm{mg} \%$. Variation in leaf chlorophyll content can provide information about the physiological condition of a leaf or plant (Larcher, 1995).

Carotenoids play a very important role in the process of photosynthesis. Biosynthesis of carotenoids in plants is a genetic characteristic, but environmental conditions also have an essential role (Bojovic 
and Stojanovic, 2005). Also, carotenoid pigments are important for animal organisms and decrease a risk of illness such as cancer, prostate, illness of the cardiovascular system.

Table 1 The content of chlorophyll $a$ in the leaves of plants of genus of Galega L., mg\% per fresh mass

\begin{tabular}{|l|c|c|c|c|}
\hline Sample & Spring vegetation & Budding & Flowering stage & Fruitage \\
\hline G. officinalis cv. Harant & $2.04 \pm 0.07$ & $2.09 \pm 0.06$ & $1.51 \pm 0.04$ & $1.20 \pm 0.02$ \\
\hline G. officinalis cv. Flamingo & $1.82 \pm 0.06$ & $2.05 \pm 0.01$ & $1.87 \pm 0.08$ & $1.88 \pm 0.01$ \\
\hline G. orientalis cv. Kavkazskiy branets & $1.56 \pm 0.01$ & $1.61 \pm 0.06$ & $2.00 \pm 0.19$ & $1.25 \pm 0.03$ \\
\hline G. orientalis cv. Saliut & $2.02 \pm 0.03$ & $1.49 \pm 0.06$ & $1.88 \pm 0.06$ & $1.87 \pm 0.04$ \\
\hline G. orientalis cv. NBS-75 & $1.43 \pm 0.01$ & $1.52 \pm 0.07$ & $2.38 \pm 0.19$ & $1.27 \pm 0.10$ \\
\hline G. orientalis cv. Riabchik & $1.92 \pm 0.04$ & $1.27 \pm 0.01$ & $1.86 \pm 0.07$ & $1.66 \pm 0.07$ \\
\hline
\end{tabular}

Table 2 The content of chlorophyll $b$ in the leaves of plants of genus of Galega L., $\mathrm{mg} \%$ per fresh mass

\begin{tabular}{|l|c|c|c|c|}
\hline Sample & Spring vegetation & Budding & Flowering stage & Fruitage \\
\hline G. officinalis cv. Harant & $0.50 \pm 0.02$ & $0.50 \pm 0.09$ & $0.38 \pm 0.09$ & $0.24 \pm 0.04$ \\
\hline G. officinalis cv. Flamingo & $0.42 \pm 0.02$ & $0.52 \pm 0.01$ & $0.53 \pm 0.10$ & $0.44 \pm 0.07$ \\
\hline G. orientalis cv. Kavkazskiy branets & $0.19 \pm 0.01$ & $0.31 \pm 0.02$ & $0.55 \pm 0.01$ & $0.40 \pm 0.03$ \\
\hline G. orientalis cv. Saliut & $0.20 \pm 0.02$ & $0.37 \pm 0.04$ & $0.56 \pm 0.01$ & $0.53 \pm 0.08$ \\
\hline G. orientalis cv. NBS-75 & $0.28 \pm 0.03$ & $0.36 \pm 0.01$ & $0.58 \pm 0.12$ & $0.35 \pm 0.01$ \\
\hline G. orientalis cv. Riabchik & $0.25 \pm 0.03$ & $0.31 \pm 0.02$ & $0.52 \pm 0.02$ & $0.43 \pm 0.02$ \\
\hline
\end{tabular}

The possible justification could be that chlorophyll $a$ is the primary pigment while other pigments including chlorophyll $b$ are accessory pigments (Srichaikul at al., 2011; Kamble et al., 2015).

In Table 3 represented data of carotenoid concentration in the leaves of species of genus of Galega. Investigated plants accumulated carotenoids in the spring vegetation from 0.31 to $0.88 \mathrm{mg} \%$, in the budding period - from 0.66 to $0.87 \mathrm{mg} \%$, in the flowering stage - from 0.51 to $1.05 \mathrm{mg} \%$, in fruitage period - from 0.57 to $0.85 \mathrm{mg} \%$. The greatest values of carotenoid content were recorded in the flowering stage for plants of G. orientalis cv. NBS-75.

Table 3 The content of carotenoids in the leaves of plants of genus of Galega L., $\mathrm{mg} \%$ per fresh mass

\begin{tabular}{|l|c|c|c|c|}
\hline Sample & Spring vegetation & Budding & Flowering stage & Fruitage \\
\hline G. officinalis cv. Harant & $0.88 \pm 0.02$ & $0.85 \pm 0.02$ & $0.51 \pm 0.01$ & $0.57 \pm 0.04$ \\
\hline G. officinalis cv. Flamingo & $0.80 \pm 0.02$ & $0.87 \pm 0.02$ & $0.76 \pm 0.01$ & $0.81 \pm 0.01$ \\
\hline G. orientalis cv. Kavkazskiy branets & $0.31 \pm 0.03$ & $0.76 \pm 0.07$ & $0.88 \pm 0.06$ & $0.60 \pm 0.03$ \\
\hline G. orientalis cv. Saliut & $0.34 \pm 0.07$ & $0.73 \pm 0.01$ & $0.85 \pm 0.02$ & $0.85 \pm 0.03$ \\
\hline G. orientalis cv. NBS-75 & $0.39 \pm 0.05$ & $0.76 \pm 0.01$ & $1.05 \pm 0.04$ & $0.57 \pm 0.03$ \\
\hline G. orientalis cv. Riabchik & $0.32 \pm 0.03$ & $0.66 \pm 0.01$ & $0.83 \pm 0.02$ & $0.78 \pm 0.02$ \\
\hline
\end{tabular}


According to Paliy et al. (2011) the content of carotenoids in Galega officinalis plants was $6.6 \mathrm{mg} \%$ that is 7.5 times more comparing with our maximal sign.

Analyzing data from Figure 1 it should be noted the ratio of chlorophylls concentration was in spring vegetation in range from 4.08 to 10.10 , in the budding period - from 3.94 to 5.19 , in flowering stage from 3.36 to 4.11 , in fruitage period - from 3.12 to 5.00. According to the majority of investigators, the ratio between chlorophylls $a$ and $b$ is $3: 1$. The weight ratio of chlorophyll $a$ and chlorophyll $b$ is an indicator of the functional pigment equipment and light adaptation of the photosynthetic apparatus (Bojovic and Stojanovic, 2005).

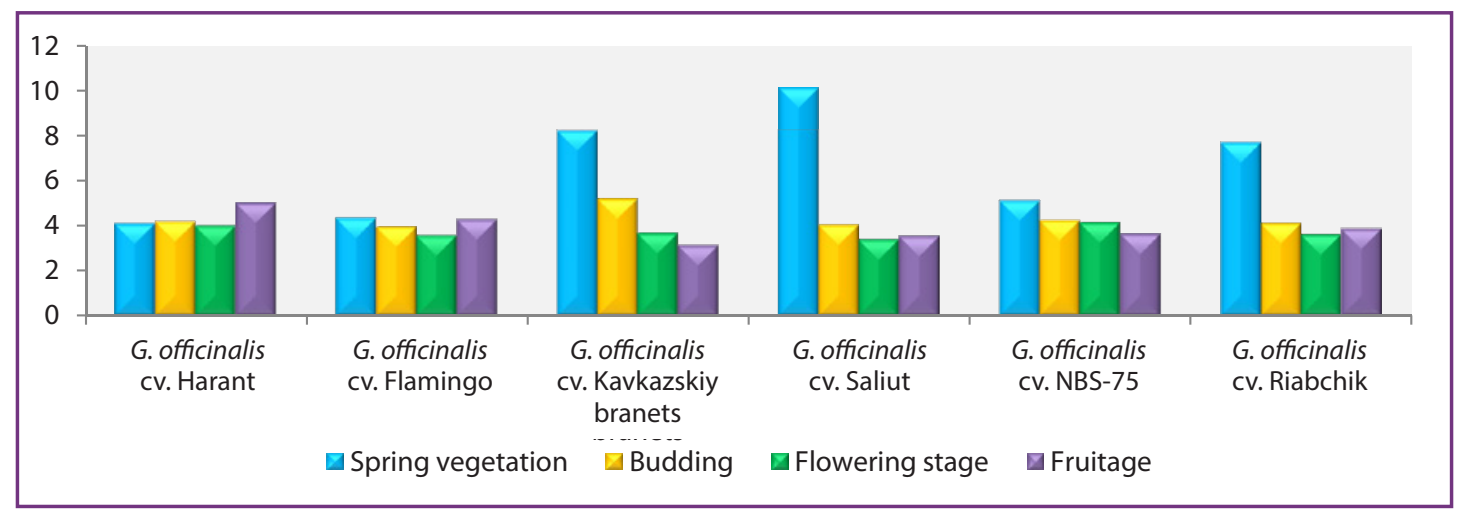

Figure 1 The chlorophyll content ratio $a / b$ in the leaves of plants of genus of Galega L.

In Figure 2 demonstrated ratio of sum of chlorophylls to carotenoid content during vegetation. At spring vegetation ratio of chlorophylls content to carotenoid content was from 2.80 to 6.79 , in budding stage - from 2.40 to 3.05 , in flowering stage - from 2.82 to 3.71 , in fruitage - from 2.53 to 2.86 .

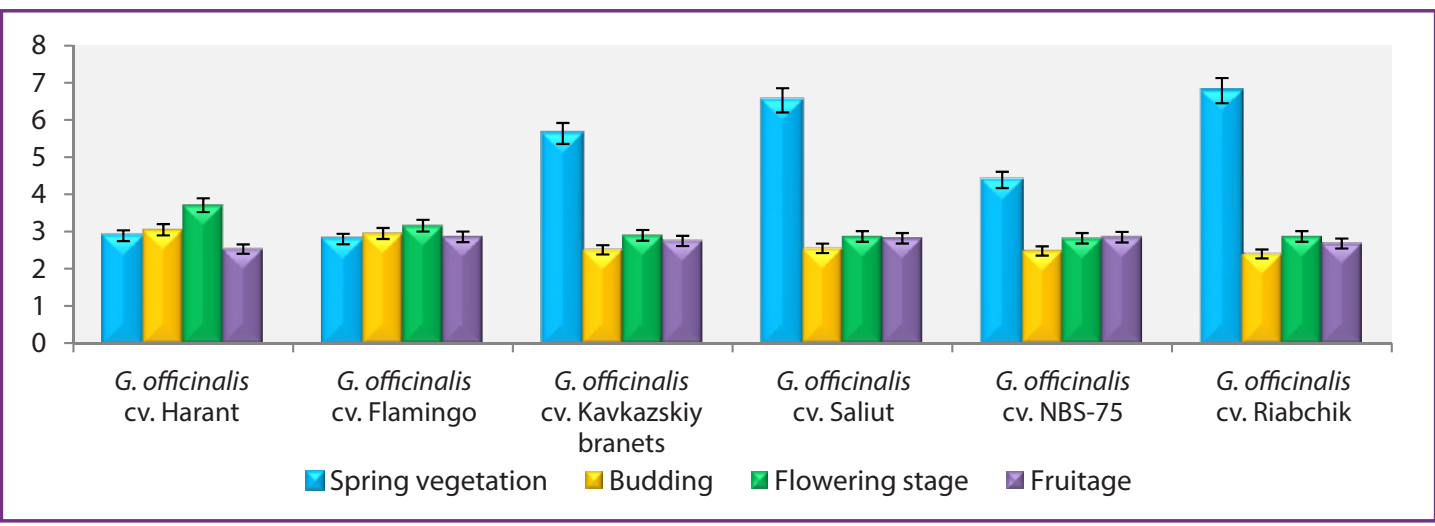

Figure 2 The ratio of the content of the sum of chlorophylls to carotenoids in the leaves of plants of genus of Galega L.

According to Penuelas et al. (1995) increasing in the relative concentration of carotenoids are often observed when plants are subjected to stress. The weight ratio of chlorophylls to carotenoids is an indicator of the greenness of plants. It is normally from 4.2 to 5.0 in sun leaves and sun-exposed 
plants, and between 5.5 and 7.0 in shade leaves and shade-exposed plants. Lower values of this ratio are an indicator of senescence, stress, and damage to the plant and the photosynthetic apparatus (Brix, 1962).

\section{Conclusions}

Thus, in conditions of M.M. Gryshko National Botanical Garden of the NAS of Ukraine the plants of cultivars of Galega officinalis and Galega orientalis accumulated chlorophyll a in the leaves more than chlorophyll b. Obtained data have resulted that for all cultivars of Galega officinalis and Galega orientalis the chlorophyll a concentration was higher than that of chlorophyll b. In addition, different ratio between a sum of chlorophylls and carotenoid content says about various functional pigment equipment and light adaptation (3.12-10.10 for $a / b$ and 2.40-6.79 for $(a+b) /$ car). The most accumulation of chlorophyll $a, b$ and carotenoid concentration was fixed for G. orientalis cv. NBS-75 $(2.38,0.58$ and $1.05 \mathrm{mg} \%$ respectively).

\section{References}

Balazentiene, L., Mikulioniene, S. 2006. Chemical composition of galega mixtures silages. Agronomy Research, vol. 4, no. 2, p. 483-492.

Balazentiene, L., Spruogis, V. 2011. Experience of fodder galega (Galega orientalis Lam.) and traditional fodder grasses use for forage production in organic farm. Veterinary Medicine and Zootechnic, vol. 56, no. 78, p. 19-26.

Bojovic, B., Stojanovic, J. 2005. Chlorophyll and carotenoid content in wheat cultivars as a function of mineral nutrition. Archives of Biological Sciences, vol. 57, no. 4, p. 283-290.

Brix, H. 1962. The effect of water stress on the rates of photosynthesis and respiration in tomato plants and loblolly pine seedlings. Physiology of Plants, vol. 15, p. 10-20.

Champavier, Y., Comte, G., Vercauteren, J., Allais, D.P., Chulia, A.J. 1999. Norterpenoid and sesquiterpenoid glucosides from Juniperus phoenicea and Galega officinalis. Phytochemistry, vol. 50, p. 1219-1223.

Kamble, P.N., Giri, S.P., Mane, R.S., Tiwana, A. 2015. Estimation of chlorophyll content in young and adult leaves of some selected plants. Universal Journal of Environmental Research and Technology, vol. 5, no. 6, p. 306-310.

Karakas, F.P., Yildirim, A., Turker, A. 2012. Biological screening of various medicinal plant extracts for antibacterial and antitumor activities. Turkey Journal of Biology, vol. 36, p. 641-652. DOI: 10.3906/ biy-1203-16

Larcher, W. 1995. Ecophysiology and stress physiology of functional groups. New York: Springer-Verlag, 528 p. ISBN 0-387-58116-2.

Musienko, M.M., Parshykova, T.V., Slavnyi, P.S. 2001. Spectrophotometric methods in plant physiology, biochemistry and ecology practice. Kyiv: Phytosociocentr, 200 p. ISBN 966-7938-09-3.

Ozbucak, T.B., Erturk, O., Akcin, O.E. 2005. An ecological, anatomical and microbiological investigation on species Galega officinalis L. (Leguminosae) in some localities of Turkey. Pakistan Journal of Biological Sciences, vol. 8, no. 9, p. 1215-1220. DOI: 10.3923/pjbs.2005.1215.1220

Paliy, A.E., Logvinenko, I.E., Logvinenko L.A., Grebennikova, O.A., Vinogradov, B.A. 2011. Biologically active compounds of Galega officinalis L. Proceedings of the Nikitsky Botanical Garden, vol. 133, p. 152-159.

Palta, J.P. 1990. Leaf chlorophyll content. Remote Sensing Reviews, vol. 5, no. 1, p. 207-213.

Peiretti, P.G., Gai, F. 2006. Chemical composition, nutritive value, fatty acid and amino acid content of Galega officinalis L. during its growth stage and in regrowth. Animal Feed Science and Technology, vol. 130, issues 3-4, p. 257-267. DOI: http://dx.doi.org/10.1016/j.anifeedsci.2006.01.007 
Shojaee, S.S., Vahdati, A., Assaei, R., Sapehrimanesh, M. 2015. Effect of Galega officinalis leaf powder and Trigonella foenum-graecum seed powder on blood glucose levels and weight gain in a diabetes mellitus rat model. Comparative Clinical Pathology, vol. 24, p. 145-148. DOI: 10.1007/s00580-013-1873-7

Srichaikul, B., Bunsang, R., Samappio, S., Butkhup, S., Bakker, G. 2011. Comparative study of chlorophyll content in leaves of Thai Morus alba L. species. Plant Science Research, vol. 3, p. 17-20. DOI: 10.3923/ psres.2011.17.20

Vergun, O.M., Shymanska, O.V., Rakhmetov, D.B. 2012. Biochemical characteristic of Galega L. species in Right-Bank Forest-Steppe of Ukraine. Odesa National University Gerald. Biology, vol. 17, no. 3 (28), p. 43-50.

Vorobei, V.S., Kovalevska, T.M., Rakhmetov, D.B. 2007. The influence of Rhizobium galegae strains on the development of plants of Galega officinalis at first and second year of cultivation. Agricultural microbiology, vol. 6, p. 113-122. http://dspace.nbuv.gov.ua/handle/123456789/23795 